Research Report

\title{
The Effect of Identification and Management of Dental Health Problems on Kindergarten and Elementary School Teachers Knowledge Levels in Keputih Public Health Center (Puskesmas)
}

\author{
Secondini Hillary Siswanto, Janery Fidelia Abraham, Nisrina Qurrota 'Aini, Meidy Damayanti, Ananta Ayu \\ Wulansari, Vina Aprilia, I Dewa AgungWirya Guna, Hikmah Putri Sary, Tamima Izzat Nabella, Nabilah \\ Azzahra Jatiatmaja and R. Darmawan Setijanto \\ Departement Dental Public Health, \\ Faculty of Dental Medicine, Universitas Airlangga \\ Surabaya - Indonesia
}

\begin{abstract}
Background: Caries is a common dental and oral health problem. Caries is one of the serious health problems for school children, especially elementary school children. Primary school-age children are susceptible to dental and oral health problems due to lack of knowledge, and they are still unable to maintain oral and dental health. The level of teacher's knowledge about dental and oral health influences students' attitudes and behavior regarding dental and oral health. Purpose: To identify the effect of identification and management of dental health problems empowerment program on kindergarten and elementary school teachers' knowledge in Keputih public health center (Puskesmas). Methods: This was an analytic observational study with a cross-sectional approach. The population was a kindergarten and elementary teachers in Keputih. Results: The result showed an increase in teachers' knowledge from 50\% to $72.5 \%$ after the intervention. Conclusions: The program concluded that there was an increase in teachers' knowledge levels regarding the identification and management of resolving dental health problems.
\end{abstract}

Keywords: school-age children; caries; teacher knowledge.

Correspondence: R Darmawan Setijanto. Department of Dental Public Health, Faculty of Dental Medicine, Universitas Airlangga, Jl. Prof. Dr. Moestopo 47 Surabaya 60132 - Indonesia. E-mail: r-darmawan-s@fkg.unair.ac.id

\section{INTRODUCTION}

In Indonesia, dental and oral health problems are ranked in the top ten diseases. This shows that dental and oral health problems in the Indonesian community environment need more attention. ${ }^{1}$ Caries is one of the common dental and oral health problems. Caries is a disease that results in demineralization, cavitation, and destruction of hard tooth tissue. It is caused by microbial activity that converts glucose from food waste into acids that can damage tooth tissue. ${ }^{2}$

Dental caries occur because bacteria damage the hard tissue of the tooth. Untreated tooth tissue damage will further progress. Tooth decay will cause pain, infection of the gums, tooth loss, and even death. To date, dental caries is still a priority issue on children's health. ${ }^{3}$ World Health Organization (WHO) in 2012 reported that $90 \%$ of school children around the world have suffered from dental caries. The Oral Health Media Center in April 2012 also reported that $60-90 \%$ of students worldwide have dental problems. $^{2}$
Caries is one of the serious health problems in students, especially elementary school students. Students generally have poor oral hygiene. ${ }^{4}$ Primary school students are vulnerable to dental and oral health problems because they may not be aware of dental hygiene. Therefore, it is important to teach children at that age about dental and oral health. ${ }^{2}$

Teachers are parents at school, and they are much responsible for children's education. ${ }^{5}$ Teacher's knowledge about dental and oral health affects students' attitudes and behavior towards dental and oral hygiene. Therefore, teachers may contribute to student's dental and oral health problems such as caries. Teachers are the role models and sources of information for students in promoting oral and dental health. ${ }^{6}$

This indicates teachers' vital role in inviting students to maintain their oral and dental hygiene, preventing oral and dental health problems, and helping students to identify and manage dental health problems as early as possible. Therefore, researchers were motivated to create and 


\section{Indonesian Journal of Dental Medicine Volume 2 Issue 1 2019; 16-18}

implement an empowerment program about the identification and management of dental health problems for kindergarten and elementary school teachers in the Keputih Public Health Center service area. Also, the researchers were motivated to investigate the effect of the empowerment program on kindergarten and elementary teachers' knowledge levels regarding dental health problems.

\section{MATERIALS AND METHODS}

Dental Health Problem Identification and Management Program provides materials that help identify and manage dental health problems. After the program, teachers are expected to help students identify and manage dental health problems. The program aimed to support the UKGS program by the Public Health Office of Surabaya. The program addressed UKGS kindergarten and elementary teachers in Keputih Public Health Center service area

Surabaya. The training of identification and management of dental health was held for one day from $13.00-15.30$ Western Indonesian Time. The training was conducted on Friday, 13 July 2018, at the Faculty of Dental Medicine of Airlangga University. The speaker was Gilang R. Sabdho Wening, drg., M.Kes.

The training consisted of a seminar, evaluation, and mentoring. The training adopted two-way communication, allowing the participants to engage with the speaker. Evaluation is carried out before and after the training (pretest and post-test). Training participants were then assisted in design empowerment programs for their schools.

Table 1. Pre-test and post-test results

\begin{tabular}{|c|c|c|}
\hline Respondent no. & Pre-test score & Post-test score \\
\hline 1 & 3 & 8 \\
\hline 2 & 5 & 6 \\
\hline 3 & 4 & 7 \\
\hline 4 & 3 & 9 \\
\hline 5 & 4 & 5 \\
\hline 6 & 6 & 10 \\
\hline 7 & 4 & 9 \\
\hline 8 & 5 & 9 \\
\hline 9 & 8 & 8 \\
\hline 10 & 4 & 7 \\
\hline 11 & 5 & 7 \\
\hline 12 & 7 & 6 \\
\hline 13 & 5 & 9 \\
\hline 14 & 4 & 9 \\
\hline 15 & 5 & 7 \\
\hline 16 & 6 & 8 \\
\hline 17 & 5 & 7 \\
\hline 18 & 9 & 7 \\
\hline 19 & 2 & 7 \\
\hline 20 & 2 & 4 \\
\hline 21 & 5 & 5 \\
\hline 22 & 7 & 4 \\
\hline 23 & 5 & 8 \\
\hline 24 & 7 & 8 \\
\hline 25 & 4 & 6 \\
\hline 26 & 6 & 8 \\
\hline 27 & 6 & 9 \\
\hline 28 & 4 & 6 \\
\hline Total & 140 & 203 \\
\hline
\end{tabular}

One of the three programs they have designed will be implemented in their respective schools per their findings of dental and oral health problems. They were then instructed to report the progress and achievements of one implemented program and elaboration on two designed programs.

The reports were then submitted to the program committee with the following format: (a) Background of the program (dental and oral health problems found); (b) The objective of the program; (c) Targets of the program; (d) Content/Material of the program; (e) Method; (f) Media; (g) Stakeholders; (h) Steps of implementation; (i) Outcomes of the program and target evaluation.

Five best reports were then selected. Five best participants then delivered presentations about their programs. Media of the program means all materials provided by the speakers covering the identification and management of dental and oral health problems. Tools and materials needed in the empowerment program are Power Point slides, module books and pre-test and post-test evaluation sheets. We analysed the pre-test and post-test data to computer teacher's knowledge levels before and after the program.

\section{RESULTS}

Pre-test and post-test were distributed in the form of questionnaires on 13 July 2018 at $13.00-13.10$ and 14.50 15.00, respectively. Questions of pre-test and post-test questionnaires were adapted from the materials provided during the seminar. The questionnaire consisted of 10 questions and should be answered in 10 minutes. Pre-test and post-test results showed significant improvements. Pre-test and post-test results.

The pre-test and post-test results indicated that the empowerment program's participants have successfully learned the theme, which was the identification and management of dental and oral health problems. The improvement was indicated in 63 scores increase from 140 in the pre-test to 203 in the post-test with a maximum score of 280 . Therefore, the teachers' knowledge levels have increased by $22.5 \%$ from $50 \%$ to $72.5 \%$.

\section{DISCUSSION}

The SWOT analysis on empowerment program: (1) Strength: This empowerment program provided teachers with the know-how to identify and manage dental and oral health problems for children with innovative, informative, and easily understood materials. Also, the program allows teachers to engage in better learning. (2) Weakness: Cost constraint on printed modules. (3) Opportunity: Supports from the school board members and the public health center (Puskesmas) have allowed the program to run smoothly. (4) Threat: Some participants failed to understand the materials and implemented the programs they designed for their schools.

This empowerment program on identification and management of dental and oral health problems involved 
Indonesian Journal of Dental Medicine Volume 2 Issue 1 2019; 16-18

28 kindergarten and elementary school teachers and took place on 13 July 2018. The program was conducted at the Faculty of Dental Medicine, Airlangga University. During the program, the participants were instructed to fill out the pre-test and post-test questions about identification and management of dental and oral health problems. The results would reflect teachers' understandings before and after the program.

The pre-test and post-test results indicated that the empowerment program's participants have successfully learned the theme, which was the identification and management of dental and oral health problems. The improvement was indicated in 63 scores increase from 140 in the pre-test to 203 in the post-test with a maximum score of 280. Therefore, the teachers' knowledge levels have increased by $22.5 \%$ from $50 \%$ to $72.5 \%$.

Dental and oral health education is an effort to increase knowledge, change behavior, and improve human habits in maintaining health. Some of the techniques and methods of health education carried out have been proven to improve the degree of human health. ${ }^{7,8}$ However, health education is often unsustainable, so an evaluation cannot be done to see an increase in knowledge to behavior changes. Therefore, we need an empowerment program that is sustainable. ${ }^{9}$ Empowerment programs not only provide material, but also train and shape behavior and habits, because it can be done continuously. Program participants are given the skills and knowledge to do something new, in this study is to identify dental and oral health problems. ${ }^{8,10}$

These results indicate a significant increase. Therefore, it can be concluded that the kindergarten and elementary school teachers have learned how to identify and manage dental and oral health problems. This was possible because the speaker directly delivered the materials. The module covers the following topics: identification of dental health problems and management of dental health problems. The two-way method has allowed participants to learn and engage with the speaker to better understand the material.

\section{CONCLUSION}

In conclusion, the empowerment program has successfully improved the kindergarten and elementary school teachers' knowledge regarding the identification and management of dental and oral health problems.

\section{REFERENCES}

1. B M, A C. 90 persen Anak SD di Bangka Sakit Gigi. Bandung: CV. Alfabeta; 2011.

2. Ningsih SU, Restuastuti T, Endriani R. Gambaran Pengetahuan dan Sikap Menyikat Gigi pada Siswa-Siswi dalam Mencegah Karies di SDN 005 Bukit Kapur Dumai. J Online Mhs Fak Kedokt [Internet]. 2016;3(2):1-11. Available from: https://jom.unri.ac.id/index.php/JOMFDOK/article/ view/9777/9440

3. Nindya Cahyaningrum A. Hubungan Perilaku Ibu Terhadap Kejadian Karies Gigi Pada Balita Di Paud Putra Sentosa Relationship of Mother Behavior Against Dental Caries Incidence in Toddler at Putra Sentosa Early Childhood. Dep Epidemiol Fak Kesehat Masy Univ Airlangga. 2017;5(April 2017):142-51.

4. Setiyawati R. Hubungan Kebiasaan Menggosok Gigi Sebelum Tidur Malam dengan Karies Pada Anak Usia Sekolah di Madrasah Ibtidaiyah Al-Istiqomah Tangerang. Univ Indones. 2012;10.

5. Dawani N, Afaq A, Bilal S. Oral health knowledge, attitude and practices amongst teachers of public school set-up of Karachi, Pakistan. J Dow Univ Heal Sci [Internet]. 2013;7(1):15-9. Available from: http://www.duhs.edu.pk/ download/jduhs-vol.7-issue-1/4.pdf

6. Tangade PS, Jain M, Mathur A, Prasad S, Natashekara M. Conhecimento, atitudes e práticas frente à cárie dentária e prevenção da doença periodontal entre professores do ensino primário em Belgaum City, Índia. Pesqui Bras Odontopediatria Clin Integr. 2011;11(1):77-83.

7. Nutbeam D, McGill B, Premkumar P. Improving health literacy in community populations: A review of progress. Health Promot Int. 2018;33(5):901-11.

8. Doyle E, Ward S, Oomen-Early J. The process of community health education and promotion. $435 \mathrm{p}$.

9. Palupi R, Berniyanti T, Bramantoro T, Wening GS, Kusumo A, Zamzam A. Local myth and facts approach for maximizing oral health promotion training among the school teachers and parents in urban village. J Int Oral Heal. 2019 Jan 1;11(7):34. Available from: http://www.jioh.org/text. asp?2019/11/7/34/250912

10. Howard BR, Cameron F. Goals: The intended outcomes of higher education. In: Investment in Learning. New York; 2018. 31-60 p. 